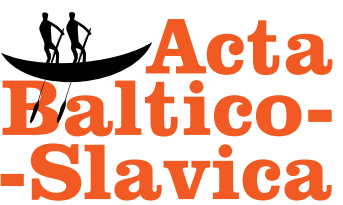

Acta Baltico-Slavica, 38

SOW, Warszawa 2014

DOI: $10.11649 /$ abs. 2014.007

\author{
Jolanta Mędelska \\ Uniwersytet Kazimierza Wielkiego \\ Bydgoszcz \\ ryba@medguz.pol.pl
}

\title{
Prasa radziecka wydawana w latach 30. XX w. w Republice Niemców Powołża. Wprowadzenie do zagadnienia i uwagi o języku'
}

Niemieccy koloniści, którzy - odpowiadając na zaproszenie zawarte w manifeście ogłoszonym przez Katarzynę $\mathrm{II}^{2} \mathrm{w}$ roku $1763^{3}$ - zaludniali i zagospodarowywali rozległe obszary ziem przyłączonych do Rosji wskutek podbojów ${ }^{4}$, musieli budować od podstaw swoje nowe życie w Rosji. W latach 1764-1766 na piaszczystym stepie po obu brzegach Wołgi osadnicy założyli 104 kolonie ${ }^{5}$. Przyszło im się mierzyć z ogromnymi

1 Artykuł powstał w trakcie realizacji projektu badawczego finansowanego ze środków Narodowego Centrum Nauki, przyznanych na podstawie decyzji numer DEC-2012/05/B/HS2/04104 (Sowietyzacja języka Niemców rosyjskich w latach 20. i 30. XX w.).

${ }^{2}$ Caryca zdecydowała się na ściągnięcie kolonistów z zagranicy nie tylko z powodu konieczności zasiedlenia rozległych niezamieszkałych obszarów kraju (ówczesna Rosja była państwem słabo zaludnionym i - ze względu na przywiązanie chłopów do ziemi - nie miała rezerwy wolnych osadników), lecz także dlatego, że zacofana rosyjska wieś potrzebowała krzewicieli nowoczesnych metod prowadzenia gospodarstwa wiejskiego, uprawy ziemi (Beratz, 1923, ss. 22-28; Зиннер, 1925, s. 1; Stricker, 1997, s. 17; Lebioda, 2004, s. 39).

3 Manifest był skierowany bezpośrednio do niemieckich chłopów, rzemieślników, fabrykantów (Остроух \& Шервуд, 1995, s. 13).

4 Proces ten trwał z pewnymi przerwami do lat 70. XIX w. (Герман \& Плеве, 2002, s. 88).

5 Inne źródła podają inne liczby, np. P. Sinner (1923, ss. 7-8) wymienia łącznie 106 kolonii, a mianowicie: po stronie gór (Bergseite): 47 osad (nr 1-47), po stronie łąk (Wiesenseite): 59 osad (nr 48-106). Liczbę 106 kolonii podaje też W. M. Żyrmunskij (Жирмунский, 1933, s. 87).

This is an Open Access article distributed under the terms of the Creative Commons Attribution 3.0 PL License (creativecommons.org/licenses/by/3.0/pl/), which permits redistribution, commercial and non-commercial, provided that the article is properly cited. (C) The Author(s) 2014. 
trudnościami: życie w szczerym polu, spanie na gołej ziemi ${ }^{6}, \mathrm{z}$ czasem - w ziemian$\mathrm{kach}^{7}$, zaorywanie ugorów, brak doświadczenia w pracy na roli ${ }^{8}$, dostosowanie się do nowych warunków klimatycznych ${ }^{9}$, dotkliwy brak opieki medycznej ${ }^{10}$, nieznajomość nowego otoczenia, najazdy okolicznych plemion, zwłaszcza kałmuckich, kradzieże koni dokonywane głównie przez ludność kałmucką, ale i przez chłopów rosyjskich, zdarzające się niekiedy porwania kobiet i dzieci. Negatywnie odbiło się też na sytuacji kolonistów powstanie Pugaczowa (1773-1775). Na ogół koloniści, nie rozumiejąc jego istoty, wrogo odnosili się do powstańców, za co oddziały powstańcze dokonywały na nich krwawych egzekucji (Зиннер, 1925, s. 5). Powstanie osłabiło pozycję państwa, a to sprzyjało wyprawom grabieżczym plemion kazachskich i kirgiskich na osady niemieckie (Beratz, 1923, ss. 159-201; Дитц, 1997, ss. 87-100; Плеве, 2000, ss. 153-174; Lebioda, 2004, ss. 76-78; Герман \& Плеве, 2002, ss. 96-97; Приб, 2007, ss. 41-43). W latach 1773-1775 wielu osadników straciło życie (Остроух \& Шервуд, 1995, s. 15).

Tak więc przez pierwsze dziesięciolecia kolonie niemieckie pozostawały w opłakanym stanie ${ }^{11}$, później warunki życia w nich bardzo się poprawiły (Плеве, 2000, s. 175). Wraz z kolonistami przybyli do Rosji duchowni, przywieźli swoje święte księgi oraz zasady moralne przewidujące surową dyscyplinę, posłuszeństwo prawu, wysoką jakość pracy. Lenistwo, rozwiązłość, pijaństwo zdecydowanie potępiano. Jak pisze Aleksander Prib, za najwyższe cnoty uważano umocnienie rodziny, wychowanie dzieci i wpojenie im nawyków pracy, a także porządek w obejściu, czystość, uczciwość w wykonywaniu przyjętych na siebie obowiązków (Приб, 2007, s. 43).

Wsie, budowane przez specjalistów przysłanych przez władze rosyjskie, odznaczały się zwartą zabudową, starano się odgrodzić je od wiosek rosyjskich, ograniczyć kontakty w celu uniknięcia konfliktów. Koloniści byli ludźmi wolnymi, ale nie mogli mieć poddanych (Lebioda, 2004, ss. 78-80). Osiedlano ich w okręgach (po ok. 1000 rodzin w okręgu) według kryterium wyznaniowego, co miało zapobiec ewentualnym sporom

6 Tereny nad Wołgą były w zasadzie pozbawione lasów, więc dotkliwie brakowało drewna (materiału na domy i zabudowania gospodarcze) (Brandes, 1997, s. 57; Lebioda, 2004, s. 74).

7 Niektórzy przybysze musieli w nich przetrwać 2-3 zimy (Зиннер, 1925, s. 3).

${ }^{8}$ Według Petrusa Sinnera około $40 \%$ przybyłych stanowili rzemieślnicy, głównie wiejscy rzemieślnicy: kowale, stolarze, tkacze, szewcy (Зиннер, 1925, s. 3).

9 „Średnie temperatury zimą odpowiadały warunkom skandynawskim, a zamarzająca Wołga [...] stawała się w zimie przez długie miesiące nieżeglowna. W lecie natomiast przez 5 miesięcy panowały upały upodabniające klimat kolonii do warunków występujących na Półwyspie Iberyjskim, i to w jego południowej części” (Lebioda, 2004, s. 73).

${ }^{10}$ Brakowało wody zdatnej do picia, kolonistów dziesiątkowała malaria i inne choroby endemiczne (Зиннер, 1925, s. 4). W jednej z osad pod Saratowem z 504 przybyłych kolonistów do roku 1775 zmarło 308 osób (Фукс, 1995, s. 23).

${ }^{11}$ Pierwsze dziesięciolecie spędzone przez kolonistów nad Wołgą to były lata nieustannego nieurodzaju (Beratz, 1923, ss. 75-82; Зиннер, 1925, s. 3; Фукс, 1995, s. 23; Brandes, 1997, s. 58). Z powodu suszy w latach 1773 i 1774 rząd musiał przyznać kolonistom dodatkowe środki finansowe (Плеве, 1995, s. 31). 
na tle religijnym (Плеве, 2000, s. 119; Герман \& Плеве, 2002, s. 94). Utworzono 33 kolonie katolickie i 68 ewangelickich (Фукс, 1995, s. 20).

Osadnicy nadwołżańscy od początku mieli własny samorząd, zwoływali zgromadzenia gospodarzy, wybierali sołtysa, a także swoich przedstawicieli do władz okręgowych. Jednak - jak uważa Tadeusz Lebioda - samorządność pogłębiała izolację wiosek niemieckich nie tylko w słowiańskim otoczeniu, ale też oddzielała je od innych niemieckich kolonii (2004, s. 83).

Koloniści osiadli nad Wołgą stali się pierwszymi przedstawicielami nowej narodowości na terytorium Rosji: Niemców nadwołżańskich (Ерина, 1995, s. 4).

Kolonie rozkwitały szczególnie w latach 1797-1845 (Bonwetsch, 1919, ss. 48-87; Приб, 2007, ss. 56-63). Niemcy zajmowali się głównie uprawą roli. Wcześnie, bo już w początkach XIX w., nastawili swoje gospodarstwa na sprzedaż zboża, zwłaszcza pszenicy. Koloniści osiągali lepsze plony niż pozostali rolnicy. Ważne miejsce zajmowała uprawa tytoniu, w której Niemcy się wyspecjalizowali, a także uprawa ziemniaków i arbuzów. Koloniści byli pionierami w hodowaniu słoneczników, gorczycy, buraka cukrowego, niemal wszyscy uprawiali warzywa (Булычев, 1995, ss. 166-170; Герман, Иларионова, \& Плеве, 2007, ss. 108-109). Obok rolnictwa rozwijał się handel, a także rzemiosło (wytwarzanie sprzętu rolniczego: pługów, wialni, wozów) i drobna przedsiębiorczość (tkactwo ${ }^{12}$, młynarstwo, wyrób masła, warzenie piwa) (Булычев, 1995, ss. 170-172; Дитц, 1997, ss. 268-279; Brandes, 1997, ss. 67-68; Приб, 2007, ss. 65-69; Литвинова, 2007, ss. 64-69; Герман, Иларионова, \& Плеве 2007, ss. 108-110).

W drugiej połowie XIX w. na dobrej dotąd sytuacji Niemców rosyjskich odbiły się negatywnie tzw. „wielkie reformy" ${ }^{\prime 3}$ przeprowadzone w Rosji w latach 1861-1870 (zniesienie pańszczyzny ${ }^{14}$, reforma ziemska, sądownicza, miejska, uniwersytecka, reformy wojskowe i finansowe, reforma cenzury). Językiem administracji we wsiach stał się rosyjski, w nim prowadzono korespondencję urzędową ${ }^{15}$. Dekret Aleksandra II wydany w czerwcu $1871 \mathrm{r}$. odebrał Niemcom wszystkie przywileje, w tym status kolonisty i samodzielne zarządzanie koloniami. W $1874 \mathrm{r}$. wprowadzono powszechny obowiązek służby wojskowej, który objął też Niemców (Brandes, 1997, ss. 89-90; Герман, Иларионова, \& Плеве, 2007, ss. 139-141; Lebioda, 2004, ss. 146-156). Pobór do wojska był jedną z najważniejszych przyczyn, które skłoniły znaczną część

12 Wytwarzano tkaninę wełnianą (sarpinkę), początkowo jednak tylko w systemie nakładczym (Lebioda, 204, s. 135).

${ }^{13}$ Jak pisze Tadeusz Lebioda: „U ich podstaw leżała porażka imperium rosyjskiego w [...] wojnie krymskiej oraz zaistniały na tle osłabienia Rosji na arenie międzynarodowej wzrost nastrojów nacjonalistycznych" (2004, s. 146).

${ }_{14}$ Zrównało niemieckich kolonistów z chłopami rosyjskimi, odbierając im tym samym nadane wcześniej przywileje.

${ }^{15}$ Lebioda, 2004, s. 147. 
Niemców rosyjskich (zwłaszcza menonitów) do emigracji za ocean (Brandes, 1997, s. 94; Lebioda, 2004, ss. 151-156). Dochodziło też do migracji wewnątrz kraju, m.in. na Syberię (Lebioda, 2004, ss. 156 -158; Герман, Иларионова, \& Плеве, 2007, s. 195). Kolonie niemieckie zaczęły podupadać.

Wraz z wybuchem I wojny światowej drastycznie pogorszyła się sytuacja Niemców w Rosji, w tym sytuacja gospodarcza. Jak napisał T. Lebioda: „Od lata 1914 r. rosyjska opinia publiczna przestała ostatecznie robić różnicę między wrogiem zewnętrznym a Niemcami we własnym kraju" (2004, s. 169). Mimo lojalnej postawy Niemców wobec nowej ojczyzny w Rosji doszło do wybuchu nastrojów antyniemieckich oraz do stosowania represji ze strony rządu. Zamknięto niemieckie szkoły i gazety, zakazano publicznego posługiwania się językiem niemieckim, bojkotowano niemieckie sklepy i przedsiębiorstwa. W lutym 1915 r. wprowadzono tzw. ustawę likwidacyjną, zmuszającą Niemców do sprzedania bądź pozbycia się w inny sposób posiadłości ziemskich i zakazującą ich nabywania (Lebioda, 2004, ss. 169-174; Герман, Иларионова, \& Плеве, 2007, ss. 223-228) ${ }^{16}$.

Po detronizacji cara Mikołaja II rozpoczęły się w Rosji przemiany demokratyczne. $\mathrm{Na}$ fali tych przemian mniejszości narodowe, w tym mniejszość niemiecka, zaczęły się domagać prawa do samostanowienia. Ruch autonomiczny miał szanse powodzenia na Powołżu, gdzie Niemcy zamieszkiwali na zwartym obszarze. W styczniu 1924 r. została powołana Autonomiczna Socjalistyczna Republika Radziecka Niemców Powołża (ASRR NP), autonomiczny twór narodowo-tery torialny w składzie Rosyjskiej Federacyjnej Republiki Radzieckiej. W roku 1926 mieszkało w niej blisko 380000 Niemców (oraz ponad $40000 \mathrm{w}$ pobliskim obwodzie saratowskim) (Eisfeld, 1987, ss. 49-55; Lebioda, 2004, ss. 176-184; А. Герман \& Е. Герман, 2006, s. 271).

W marcu 1921 r. X Zjazd Rosyjskiej Komunistycznej Partii (bolszewików) [RKP(b)] ogłosił tzw. nową leninowską politykę narodowościową przewidującą znaczne poszerzenie praw mniejszości, umożliwienie im rozwijania kultury w językach ojczystych, tworzenia literatury, wydawania prasy, a także uruchamiania własnych placówek oświatowych i kulturalnych (Iwanow, 1991, s. 35). W rejonach autonomicznych języki mniejszości stały się urzędowymi, w Republice Niemców Nadwołżańskich za urzędowy uznano niemiecki (Lebioda, 2004, s. 199). W ramach nowej polityki w latach 20. XX w. w ASRR NP uruchomiono m.in. Niemiecką Wyższą Szkołę Pedagogiczną, Wyższą Szkołę Wieczorową, Wyższą Szkołę Rolniczą, technikum przemysłowo-ekonomiczne, technikum handlu radzieckiego, wieczorowe technikum przedszkolno-bibliotekarskie, szkołę muzyczną, liceum pedagogiczne, szkołę rolniczą, felczersko-akuszerską, dwie szkoły zawodowe, Centralne Archiwum ASRR NP, wydawnictwo Nemgosizdat, Centralne Muzeum ASRR NP (Дизендорф, 2006, s. 323). Jak pisze Walentyna

16 Zob. też: Айсфельд, 1995, 2005; Бобылева \& Кадол, 2005. 
Czebotariewa, w połowie lat 30. XX w. w Republice Niemców Powołża stworzono solidną materialno-techniczną bazę dla rozwoju kultury. Oddano do użytku 20 domów kultury, 286 świetlic, 240 klubów kołchozowych, w miastach i dużych wsiach działało 128 bibliotek, w których zgromadzono pokaźny księgozbiór (600 tys. woluminów) (Чеботарева, 1999, s. 326). W ASRR NP zaczęto masowo drukować po niemiecku gazety, broszury, książki, podręczniki, słowniki, dokumenty, sprawozdania, zwłaszcza zaś materiały propagandowe. Nowa polityka narodowościowa władz radzieckich sprowadzała się oczywiście do szybkiego i sprawnego indoktrynowania mniejszości narodowych, „wychowywania” ich w duchu ideologii komunistycznej (Iwanow, 1991, s. 369; Lebioda, 2004, s. 199). Celem polityki kulturalnej była sowietyzacja, oznaczająca jednocześnie rusyfikację mniejszości narodowych (Pinkus \& Fleischhauer 1987, ss. 148-149). Temu celowi służyła też niemiecka prasa radziecka, tak jak i miejscowa literatura - „narodowa w formie, socjalistyczna w treści” ${ }^{\prime 7}$.

Niemiecka prasa w Rosji ma ponad 200-letnią historię i wiąże się z reformatorskim ruchem Piotra I. To właśnie niemiecka "Sankt Petersburger Zeitung” ukazująca się od 1727 r. była drugą gazetą założoną w Rosji1 ${ }^{18}$ (Смирницкая, 2002, s. 239). Wiek XVIII aż po lata 70. XIX w. uważa się za okres kształtowania się czasopiśmiennictwa niemieckiego w Rosji i nabierania przez nie charakteru lokalnego. Wychodzące wówczas periodyki utrzymały się w zasadzie do 1914 r. Były źródłem informacji przede wszystkim o wydarzeniach lokalnych. Co ciekawe, w największym skupisku Niemców rosyjskich, na Powołżu, bardzo długo nie wydawano prasy. Jak tłumaczy Tatiana Iłarionowa, w środowisku chłopskim ${ }^{19}$ w ogóle nie było zapotrzebowania na gazetę - jest to zjawisko miejskie. Prasa zaczęła się tam pojawiać dopiero w drugiej połowie XIX w., w okresie rozkwitu gospodarczego kolonii nadwołżańskich i związanego z nim rozwoju kultury ich mieszkańców (Иларионова, 2006, ss. 68-71). Pierwszą niemiecką gazetą wydawaną na Powołżu była „Deutsche Volkszeitung”"20 (Смирницкая, 2002, s. 240).

Wybuch I wojny światowej to kres istnienia prasy niemieckiej w Rosji carskiej. Niemal natychmiast zamknięto prawie wszystkie czasopisma (tylko 3 gazety niemieckojęzyczne wychodziły do czerwca 1916 r.) (Busch, 1997, s. 515). Miało to bezpośredni związek z wprowadzeniem zakazu posługiwania się językiem niemieckim $\mathrm{w}$ sferze publicznej (Иларионова, 2006, s. 73). Jednak od roku 1916 w Jekaterynosztadcie zaczęto wydawać socjalistyczną gazetę „Kolonist”, z czasem (od 1918 r.) przemianowaną na „Kommunist” (Зиннер, 1925, s. 14).

17 Por. tytuł artykułu Annelore Engel-Braunschmidt: „National nach der Form, dem Inhalt nach sozialistisch". Zur besonderen Situation der deutschen Literatur in der Sowjetunion (1987, ss. 115-135). O pojawieniu się niemieckiej literatury proletariackiej zob.: Герман, Иларионова, \& Плеве, 2007, ss. 402-405.

${ }_{18}$ Wyszła w Sankt-Petersburgu (2 lata po śmierci Piotra I).

19 Ludność chłopska zdecydowanie przeważała wśród mieszkańców tego regionu.

${ }^{20}$ Lata 1864-1915, Saratów. 
Prasa niemiecka odrodziła się po rewolucji październikowej. Do jej wskrzeszenia doszło tam, gdzie później powstały najważniejsze polityczno-narodowe instytucje Niemców rosyjskich, czyli na Powołżu. W Republice Niemców Powołża została utworzona rozgałęziona sieć wydawnictw periodycznych (Чеботарева, 1999, s. 328). Pierwsza gazeta nosiła tytuł „Saratower Deutsche Zeitung”. Odzwierciedlała walkę Niemców rosyjskich o prawo do samostanowienia, pisała o sprawach lokalnej społeczności niemieckiej (Чеботарева, 1999, s. 328; Иларионова, 2006, s. 73). Jednak porewolucyjne zmiany społeczno-polityczne sprawiły, że wkrótce niemiecka prasa radykalnie zmieniła swój charakter. W listopadzie 1917 r. W. I. Lenin podpisał Dekret o prasie, którym zdecydowanie zakazał wydawania periodyków o charakterze „kontrrewolucyjnym”. Zakazem objęto nie tylko prasę opozycyjną, ale po prostu wszystkie wydawnictwa niebolszewickie. Od tej chwili prasa radziecka była całkowicie kontrolowana, podporządkowana partii i państwu (Busch, 1997, s. 515; Иларионова, 2006, s. 73). Partia bolszewicka widziała w gazetach „zbiorowego propagandystę, agitatora i organizatora”. Dla redaktorów gazet w języku niemieckim oznaczało to konieczność współuczestniczenia w bolszewizowaniu kolonii niemieckich (Иларионова, 2006, s. 73).

Do połowy lat 20. XX w. drukowano w całym ZSRR ponad 70 niemieckojęzycznych periodyków (Busch, 1997, s. 515). W Republice Niemców Powołża wydawano 21 gazet w języku niemieckim. Były wśród nich także czasopisma specjalistyczne, np. w latach 1922-1929 wychodziła gazeta pedagogiczna "Wolgadeutsches Schulblatt”, bardzo popularna wśród niemieckich nauczycieli. Wtedy też ukazywała się „Unsere Wirtschaft”21, „Sei bereit” (dla pionierów), „Rote Jugend” (dla komsomolców ${ }^{22}$ ), wychodziły liczne gazety kantonowe (Смирницкая, 2002, s. 240). W związku z zakazem wydawania czasopism niebolszewickich niektóre fachowe pisma musiały zmieniać tytuły, np. „Wolgadeutsches Schulblatt” na „Zur Neuen Schule” (1925-1927), potem na „Revolution und Kultur” (1930-1935). Największą liczbę niemieckich periodyków wydawanych w ZSRR 90 notowano w roku 1934. W kolejnych latach ich liczba spadła do 33 (Busch, 1997, s. 515).

$\mathrm{W}$ połowie lat 20. XX w. władza radziecka ustaliła, jak należy prowadzić pracę ideowo-polityczną z ludnością miejską, a jak z wiejską, wydając specjalne rozporządzenie $O$ rodzaju gazet robotniczych i chłopskich. Tym samym, jak trafnie zauważyła Tatiana Iłarionowa, „dokładnie określono, kto w ZSRR jaką ma czytać prasę”23 (2006, s. 74).

$\mathrm{W}$ okresie pierwszych pięciolatek prasa radziecka pozostawała pod wpływem dwóch przeciwstawnych tendencji. Z jednej strony - ze względów ideowo-politycznych władzom zależało na zwiększaniu liczby tytułów prasowych, $\mathrm{z}$ drugiej zaś - z braku środków finansowych - trzeba było stale zmniejszać nakłady, okrawać formaty,

21 W połowie lat 20. - dwutygodnik (Зиннер, 1925, s. 13).

22 Nakład: 10 tys. egzemplarzy (Чеботарева, 1999, s. 328).

23 „ [...] принято постановление [...], которое и определило, кому какую в СССР читать прессу”. 
ograniczać liczbę stron, a nawet likwidować niektóre tytuły (Busch 1997, s. 516; Гepман, Иларионова, \& Плеве, 2007, s. 408).

W latach 30. XX w. zaczęto kształtować prasę według wzorca administracyjno-terytorialnego, czyli wydawać gazety centralne i obwodowe. Dodatkowo w roku 1931 wyszło rozporządzenie $O$ wiejskiej prasie rejonowej $i$ dołowej ${ }^{24}$, na którego podstawie zaczęły się burzliwie rozwijać gazety rejonowe. Ich odpowiednikiem w ASRR NP stała się prasa kantonowa (zgodnie z podziałem administracyjnym tej republiki na kantony). Wkrótce potem, w roku 1933, nakazano także wydawanie prasy w kołchozach, sowchozach, ośrodkach maszynowych ${ }^{25}$, tzw. MTS (ros. машинно-тракторная станция, MTC, niem. Maschinen-Traktoren-Stationen, MTS), więc i we wsiach na Powołżu zaczęto drukować gazety (Pinkus \& Fleischhauer, 1987, ss. 135-144; Busch, 1997, s. 516; Иларионова, 2006, s. 74; Герман, Иларионова, \& Плеве, 2007, s. 408). Nakaz wydawania gazet na wsiach wiązał się z utworzeniem wydziałów politycznych przy ośrodkach maszynowych i sowchozach. Aby tzw. prasa „dołowa”26 mogła się rozwijać bez przeszkód, do ASRR NP dostarczono 6 maszyn drukarskich z czcionką niemiecką, które zostały przydzielone wybranym ośrodkom maszynowym (MTS). W roku 1934 na mocy rozporządzenia komitetu obwodowego partii przy Wyższej Komunistycznej Szkole Rolniczej uruchomiono kursy przygotowujące drukarzy. Skierowano na nie 30 osób (po 1-2 z każdego kantonu) i utworzono dwie grupy: jedną w języku niemieckim, drugą - w rosyjskim (Чеботарева, 1999, s. 328). Kierownictwo niemieckich kantonów ASRR NP starało się wiernie odtworzyć w miniaturze cały system prasy radzieckiej, np. w kantonie balcerskim w pierwszej połowie lat 30. wydawano jedną gazetę partyjną, jedną radziecką, jedną młodzieżową, dwie specjalistyczne i dwie MTS (Герман, Иларионова, \& Плеве, 2007, s. 409).

Prasa „dołowa”, także ta w języku niemieckim, była zazwyczaj niskonakładowa (200-500 egzemplarzy) i nierentowna, deficytowa. Kosztowne wydawanie tak dużej liczby tytułów nie tylko nie przynosiło zysków finansowych, ale też nie spełniało niematerialnych, ideowo-politycznych oczekiwań władz. Kwalifikacje i kompetencje ogromnej rzeszy obwodowych „dziennikarzy” radzieckich były bardzo niskie. Pisali z konieczności pośpiesznie, niestarannie, popełniali liczne błędy (Герман, Иларионова, \& Плеве, 2007, s. 409). Gazety nagminnie zamieszczały relacje tzw. „rabkorów”"27 (korespondentów robotniczych) i „sielkorów”28 (korespondentów wiejskich), ludzi - jak napisał Abram Mieromskij ${ }^{29}$ - do niedawna bardzo dalekich od

${ }^{24}$ Ros. низовая пресca, czyli prasa przeznaczona dla tzw. „dołów” partyjnych (низов).

${ }^{25}$ To odpowiedniki państwowych ośrodków maszynowych (POM) w PRL.

${ }^{26}$ Ros. низовая пресса.

27 Ros. рабкор (рабочий корреспондент).

${ }_{28}$ Ros. селькор (сельский корреспондент).

29 Badacz ten poddał analizie listy wysyłane codziennie z wiosek i osad do redakcji periodyku „Крестьянская газета”. Zauważył, że znaczna większość korespondentów wiejskich to „ludzie ziemi” 
przelewania swoich myśli na papier (Меромский, 1930, s. 14). Ten radziecki badacz tekstów „sielkorów” dostrzegł, że w języku wsi zaczęły się pojawiać nowe terminy, nр. пропаганда (propaganda), агитация (agitacja), санитария (sanitaria), критика (krytyka), гигиена (higiena). Wprawdzie na razie używa się ich nie zawsze poprawnie, ale - jak stwierdził - to nieważne, ważne, żeby takie wyrazy zyskały także na wsi prawo obywatelstwa (Меромский, 1930, s. 104).

Charakterystyczną cechą prasy radzieckiej była powtarzalność tytułów: tak samo nazywające się gazety funkcjonowały obok siebie, np. „Bolschewik” (3 gazety), „Lenins Weg” (5 gazet), „Für bolschewistische Kollektive” (8 gazet) (Busch, 1997, s. 515; Чеботарева, 1999, s. 329). Często też spotykało się niemieckie mutacje gazet rosyjskich, np. „Трудовая правда” i „Arbeiterwahrheit” czy „Темпо. Большевистский ежедн. бюллетень” i „Tempo. Bolschewistisches Alltägl. Bulletin”. W ASRR NP wydawano też prasę w języku rosyjskim, adresowaną nie tylko do jej rosyjskojęzycznych mieszkańców, ale prawdopodobnie także do Niemców, np. „Вперед к победе”з ${ }^{\text {. }}$

Zgodnie z wytycznymi władz periodyki miały charakter propagandowo-popularyzatorski, bardzo dużo miejsca zajmowały w nich przedruki (w wypadku prasy w języku niemieckim - tłumaczenia) z gazet centralnych, czyli kompletne sprawozdania $z$ kolejnych posiedzeń czy plenów partii, przemówienia J. Stalina ${ }^{31}$ i innych prominentnych działaczy partyjnych. Wiadomości lokalne ograniczały się zazwyczaj do sprawozdań z działalności kolektywów pracowniczych, brygad polowych, do informacji o przebiegu rozmaitych kampanii politycznych i gospodarczych, np. siewnych czy żniwnych (Чеботарева, 1999, s. 330; Иларионова, 2006, s. 74; Герман, Иларионова, \& Плеве, 2007, s. 408). Mimo starań lokalnych redaktorów władze partyjne ASRR NP nie były zadowolone z poziomu zaangażowania ideologiczno-politycznego niemieckiej prasy, której redaktorzy nieszczególnie rwali się do demaskowania „wrogów ludu” (Чеботарева, 1999, s. 330).

Przedstawię tu bliżej dwie typowe gazety drukowane w połowie lat 30. XX w. w ASRR NP, obecnie przechowywane w Państwowym Archiwum Historycznym Niemców Powołża w Engelsie (Rosja).

(w czasie żniw wyraźnie spadała liczba przesyłanych materiałów) (Меромский, 1930, ss. 7-8). Kiedy tacy autorzy pisali o sprawach bardzo odległych od chłopskiej codzienności, gęściej szpikowali swoje wypowiedzi słowami książkowymi, „używając ich niekiedy «ni w pięć ni w dziewięć» («ни к селу ни к городу») (s. 15). Gdy „sielkor” słyszał w mowie osoby wykształconej wyraz перефразировать, to odbierał go swoim nieprzyzwyczajonym uchem jako перефуркразировать (s. 79).

${ }^{30} \mathrm{~W}$ dniu 23 października 1937 r. wyszło rozporządzenie nakazujące zamknięcie gazet w języku rosyjskim w tych kantonach, w których ludność rosyjska stanowiła mniejszość (Чеботарева, 1999, s. 329).

${ }^{31}$ Np. gazeta „Für bolschewistische Kollektive”, wychodząca w Spartakowskim Okręgu Niemieckim w okolicach Odessy na Ukrainie, w marcu 1939 r. pięć swoich dwuszpaltowych numerów zadrukowała całkowicie przemówieniami J. Stalina i i innych działaczy partyjnych (Герман, Иларионова, \& Плеве, 2007, s. 408). 
Wydawana w języku rosyjskim jednokartkowa gazeta „Вперед к победе” (dalej: WKP) wychodziła co 5 dni. Była organem ${ }^{32}$ Fiodorowskiego Kantonowego ${ }^{33}$ Komitetu Partii, Kantonowego Komitetu Wykonawczego oraz Kantonowej Rady Zawiązków Zawodowych. Obok tytułu i danych wydawcy figurowało - jak we wszystkich gazetach komunistycznych - hasło: Пролетарии всех стран, соединяйтесь!

W numerze 16. (96.) z 21 kwietnia 1933 r. na pierwszej stronie wydrukowano uchwałę biura politycznego Fiodorkowskiego Komitetu Kantonowego z 19 kwietnia 1933 r. O przebiegu wiosennego siewu, która podaje dokładną liczbę hektarów obsianych w poszczególnych kołchozach ${ }^{34}$. Gazeta pisze, że trzeba zacząć nagradzać przodowników pracy, by dla innych stanowili wzór do naśladowania i by poprowadzili Kanton do zwycięstwa w Republice Niemców Powołża w trwającym tam właśnie socjalistycznym współzawodnictwie z Kantonem Krasnokuckim. Postanowiono wręczyć najlepszemu kołchoźnikowi, najlepszemu siewcy i najlepszej „ogniwowej”35 po 10 rubli. Nagrodzonych gazeta wymienia z nazwiska. Redaktorzy poinformowali też o ogłoszeniu w całym Kantonie pięciodniówki współzawodnictwa socjalistycznego o zakończenie wczesnego siewu. Za pełne wykorzystanie bydła pociągowego i maszyn, za wykonanie norm oraz ich przekroczenie, za właściwe wykorzystanie krów ${ }^{36}$ ustalono następujące nagrody: dla najlepszego kołchozu - przechodni czerwony sztandar (kantonowy), 300 rubli i skrzynka machorki, dla najlepszej brygady 100 rubli oraz po jednym kuponie materiału na płaszcz dla każdego kołchoźnika, dla przewodniczącego przodującego kołchozu i najlepszego brygadzisty - po jednym płaszczu i po jednym skierowaniu na wczasy. Biuro zalecało też zebranie tysięcy podpisów przodowników pracy, potwierdzających wykonanie zobowiązania, i na łamach gazety apelowało, by surowo zwalczać pogoń kołchozów za jak największą liczbą przodowników pracy i za pseudoprzodownikami, by mobilizować kołchoźników do walki z niedobitkami kułactwa i jego agentami - oportunistami, by skrupulatnie wykonywać dyrektywy partii i jej wodza towarzysza Stalina, wówczas bowiem kołchozy będą naprawdę bolszewickie, kołchoźnicy zaś staną się ludźmi zamożnymi. $\mathrm{Na}$ drugiej stronie mamy następujące nagłówki: Odpowiadamy Komitetowi Kantonowemu: Do 25 kwietnia wykonamy swoje zadania wczesnego siewu; Nie przymykać

32 Por. zapis w nagłówku: „орган Федоровского канткома ВКП(б), КИК-а и Кантпрофсовета”.

${ }^{33}$ Kanton Fiodorowski (федоровский кантон) zajmował północno-wschodnie krańce ASRR NP. Leżał w odległości 115 km koleją od stolicy republiki, miasta Engels. Niemcy stanowili 8,4\% mieszkańców. Centrum kantonu było osiedle wiejskie Mokrous (Герман, 2006b, s. 633).

${ }^{34}$ Ивановка - 189, Калдино - 200, Красавка - 122, Митрофановка 224, Николаевка - 134, Скменовка - 136, Гнаденфлюр - 254, Зихильберг - 110, Кавелинка - 96, Мангейм - 172, Мариенбург - 120 itd.

${ }^{35}$ Ros. звеньевая (kierująca brygadą polową).

${ }^{36}$ W kołchozach nakazano używać krów jako zwierząt pociągowych, przeciwko czemu Niemcy, dobrzy gospodarze, protestowali. 
oczu na sabotowanie akcji siewnej; Odmawiają członkostwa w brygadzie; Wielkanoc zatrzymała siew ${ }^{37}$; Ukarać; Sabotażysta kinowy ${ }^{38}$. W kolejnym numerze (17. z 22 kwietnia) gazety kantonowej na pierwszej stronie przez całą jej długość wydrukowano wielką tłustą czcionką hasło: Ze wszystkich sił ciagnąć krzywa wzrostu tempa siewu w górę! Tytuły notatek prasowych wiernie odzwierciedlają ich zawartość: Wyżej tempo szturmowej pięciodniówki; Uchwała Fiodorowskiego Biura KK WLKZM; Informacja o siewie i orce na podstawie danych Kantonowego Zarzadu Rolnego. W dolnym rogu strony zamieszczono hasło: Komsomolcy, dawajcie przykład wzorowej walki o normy wykonania, o wkład pracy! Na odwrocie (na drugiej stronie) widnieje wielkie hasło wydrukowane tłustą czcionką: Sztywny plan godzinowy dla każdego dnia pracy! Notatki prasowe zatytułowano następująco: Pracować zgodnie z planem; Petniej wykorzystywać, właściwie opłacać pracę krowy i kołchoźnika pracujacego na niej. Kierownik brygady Moskalenko pracuje według wskazówek kułaków; W kołchozie Mołotowa o normy nie walczą. Trzeci z rzędu numer gazety (18. z 25 kwietnia) jest tak samo monotematyczny, sztampowy i drętwy jak poprzednie. Zawiera wielkie hasło: Szybkim tempem siewu powitać i spędzić 1 Maja! Przygotowywać się do święta, biorąc wzór z kołchoźników Morgentau! Na pierwszej stronie widnieją tytuły notatek: Przygotowywać się do 1 Maja; Plan świętowania 1 Maja w Kantonie Fiodorowskim; Rocznice wspólzawodnictwa i 1 Maja powitamy zakończeniem siewu. Na drugiej stronie mamy wielkie hasło: O krótkie terminy, o wysoką jakość siewu! oraz notatki zatytułowane następująco: Tempo pozostaje wolne; Dlaczego 1,6 ha, a nie 2,7 ha; Informacja o siewie $i$ orce na podstawie danych Kantonowego Zarzadu Rolnego na dzień 24 kwietnia; Krowy wykonuja normy ${ }^{40}$; Walka $z$ sabotażem kułackim o silne kołchozy.

Drugi periodyk, który tu przedstawię, to dwujęzyczne „Темпо. Большевистский Бюллетень” // „Tеmpo. Bolschewistisches Bulletin” (TBB). Na pierwszej stronie tej jednokartkowej gazety drukowano wiadomości po rosyjsku, na drugiej zaś (na odwrocie) - przedrukowywano je po niemiecku (gotykiem) ${ }^{41}$. Gazeta była organem

37 Oto treść tej notatki: „Organizator pracy kołchozu Wozniesieńskiego, tow. Kuchajew, spędził wielkanocną noc w domu, przez co udaremnił przerzucenie brygad na inne miejsce pracy. Brygady powinny były przenieść się o północy, a przeniosły się dopiero o 10 rano następnego dnia, i to bez kierownictwa Kuchajewa, z którego winy brygady miały 10-godzinny przestój. Jednocześnie ten Kuchajew znowu dopuszcza do pracy kułacko-zamożne osoby, zwolnione z pracy za sabotażowy stosunek do siewu. Za takie zachowanie i takie kierowanie ludźmi przez Kuchajewa trzeba go ukarać”. Wszystkie cytaty w tłumaczeniu J. M.

${ }_{38}$ Киносрывщик (o pijanym mechaniku kinowym).

39 „Полнее использовать, правильно оплатить труд коровы и работающего на ней”.

40 Por.: „В Романовском колхозе «Победа» коровы выполняют нормы выработки по пахоте [...]”.

${ }^{41}$ Oprócz danych zamieszczanych u dołu strony rosyjskiej, a mianowicie: „Типография Палласов. КИКа АССРНП. Кантлит № 65. Тираж 330. Отв. редактор А. Фрицлер”. 
Pałłasowskiego Kantonowego ${ }^{42}$ Komitetu Partii i Kantonowego Komitetu Wykonawczego ASRR NP. Wychodziła codziennie.

Przyjrzyjmy się niemieckiej wersji wydania z 26 maja 1935 r. Mamy tu tytuł i numer: „Tempo. Bolschewistisches Bulletin”, № 1, 26 Mai 1935, dane o wydawcach: Organ des Pallasowkaer KK der AP (B) SU und KVA der ASSR der WD oraz hasło: Proletarier aller Länder, vereinigt Euch! Niżej podano tłustą czcionką wielki tytuł: Informacja o przebiegu kampanii zagospodarowania ugorów, pielenia i siewu na dzień 25 maja 1935 w Kantonie Pałłasowskim ${ }^{43}$, pod nim zaś zamieszczono dużą tabelę zawierającą nazwy kołchozów (Neu-Galka Nr. 1, Neu-Galka Nr. 2, Neu-Weimar, Alt-Weimar, Frankreich, Straßburg Nr. 1, Straßburg Nr. 2) ${ }^{44}$ oraz następujące rubryki: Ugory; Pielenie; Sianokosy; Zajmowane miejsce ${ }^{45}$. Rubryki te podzielono z kolei na: Plan; Zaorano w ha; Proc. wykon.; Wypielenie w ha; Proc. zasiewów; Plan; Skoszono $w$ ha; Zajmowane miejsce ${ }^{46}$. Są jeszcze rubryki: $W$ Pałłas. MTS (tu nazwy: Sawinka Nr 1, Sawinka Nr 2, Bursy, Kom. „Smytschka”, Sawinka 5, Sawinka 6); Zajmowane miejsce; W Sawinsk. MTS; W kantonie ${ }^{47}$. Resztę strony zajmuje ramka z napisem: Kto maszeruje na czele $^{48}$, w której pod nagłówkiem: Tablica honorowa ${ }^{49}$ umieszczono nazwy przodujących zespołów i nazwiska ich kierowników: 1. A-Weimar, Vorsitzd. Kolchos Wulf A., Partorg - Heinze. 2. Kom. ${ }^{50}$ Smytschka, Vorsitz. d. Kolchos - Polusmak. Drugi napis w ramce informuje: Kto haniebnie wlecze się $w$ ogonie ${ }^{51}$. W tym miejscu - pod tytułem Tablica hańby - redakcja odnotowuje: 1. N-Galka Nr. 1, Vorsitz. d. Kolchos Maier, Partorg - Hasselbach. 2. Bursy, Vorsitz. d. Kolchos Fedulow, Partorg - Oparie.

Inne numery tej gazety dostępne w Państwowym Archiwum Historycznym Niemców Powołża w Engelsie niewiele się od siebie różnią. Redaktorzy drukują wielkie hasła (np.: w numerze z 13 kwietnia 1935 r.: Walka o krótkie terminy siewu i wysoka jakość pracy to walka o wysokie plony! $!^{52}$, pod którymi umieszczają tytuły kolejnych tabel, np.: Informacja o przebiegu wiosennego siewu w Kantonie Pałłasowskim na dzień

42 Kanton Pałłasowski (палласовский кантон) zajmował południowo-wschodnie krańce ASRR NP. Leżał w odległości $213 \mathrm{~km}$ koleją od stolicy republiki, miasta Engels. Niemcy stanowili tu 51,5\% mieszkańców. Centrum kantonu było osiedle wiejskie Pałłasowka (Герман, 2006a, ss. 18-19).

${ }^{43}$ Angaben über den Gang des Brachackers Jäden und Heumad auf den 25. Mai 1935 im Pallasowkaer Kanton.

${ }^{44}$ Por. te nazwy podane na pierwszej stronie w wersji rosyjskiej: Ней-Галка, № 1, Ней-Галка, № 2, Ней- Веймар, Альт Веймар, Франкрейх, Штрасбург, № 1, Штрасбург, № 2.

${ }^{45}$ Brachen; Jäden; Heumahd; Platz.

${ }^{46}$ Plan, Gebracht in ha, Proz. zum Plan, Gejäden in ha, Proz. zur Saatfläche, Plan, Gemäht in ha, Platz.

${ }^{47}$ In der Palla. MTS; In der Saw. MTS; In allen im Kanton.

48 Wergeht voraus.

${ }^{49}$ Rote Tafel.

${ }^{50}$ Najprawdopodobniej skrót od Kommando (drużyna).

${ }^{51}$ Wer schändlich zurückbleibt.

${ }^{52}$ Kampf um kurze Saatfrist und hohe Güte der Arbeit, ist Kampf um eine hohe Ernte. 
12 kwietnia $1935^{53}$, oraz same tabele. Niżej wymienia się przodowników (na tablicy honorowej) i wlokących się w ogonie ${ }^{54}$ (na tablicy hańby).

Co się tyczy szaty językowej prasy wydawanej w ASRR NP, to - jak cała prasa radziecka - była ona pisana nowomową, czyli sztampowym, drewnianym językiem komunikowania się władzy komunistycznej ze społeczeństwem. Język ten tworzyli wewnątrz partii jej działacze. Służył do manipulowania zachowaniami i nastrojami społecznymi. Narzucał społeczeństwu jednoznaczny (zgodny z głoszoną ideologią) obraz rzeczywistości, wartościując jej elementy na dobre i złe w sposób niepozostawiający wątpliwości.

Redaktorzy gazet pośpiesznie ${ }^{55}$ drukowanych w ASRR NP byli bardziej agitatorami politycznymi niż dziennikarzami. Pisali w sposób charakterystyczny dla swojej epoki: dynamicznie, krótko, prosto, niewyszukanie, wręcz topornie, pstrząc gazety hasłami propagandowymi (por. cytowane wyżej tytuły prasowe) i obficie wykorzystując leksykę wojskową (por.: проводить жестокую борьбу с погоней за количеством ударников; мобилизовать колхозников на борьбу состатками кулачества [...] - WKP 1933/16/1) oraz zdania w formie rozkazów (por. cytowane powyżej tytuły prasowe).

Badana prasa dostarcza też ciekawego materiału leksykalnego. Na przykład w gazetach rosyjskich można natrafić na wyrazy nieodnotowane w słownikach definicyjnych języka rosyjskiego (zazwyczaj efemerydy, jednostki krótko będące w obiegu). W naszym niewielkim ekscerpcie tego rodzaju jednostką jest пятидневник (Собрать в пятидневник тысячи подписей - WKP 1933/16/1; Выме темпы ударного пятидневника - WKP 1933/17/1). Słownik Dmitrija Uszakowa (TSRJa) włączający już słownictwo lat 20. i 30. XX w., w tym pierwsze sowietyzmy, notuje tylko neologizm пятидневка: нов. 'период времени в пять дней'; także nowsze słowniki postaci пятидневник nie poświadczają (por. SSSRL, 1991). Mamy też przymiotnik кантонный: для колхоза - переходящее красное знамя (Кантонное) - WКP 1933/16/1, podczas gdy TSRJa i pozostałe źródła leksykograficzne podają tylko кантональныı̆. Nie znalazły odzwierciedlenia w słownikach ${ }^{56}$ specyficzne złożenia i zrosty utrwalone w badanych radzieckich gazetach, np.: лжеударник ${ }^{57}$ (проводить жестокую борьбу

${ }^{53}$ Angaben über den Gang der Frühjahrssaat im Pallasowkaer Kanton auf den 12. April 1935.

${ }^{54}$ W tym numerze pod nagłówkiem: Wer die Saat schändlich sprengt.

${ }_{55}$ O pośpiechu redaktorów i wynikającym z niego braku dbałości o formę świadczą liczne błędy druku, potknięcia i niedoróbki, np.: В боронбе при запряжке 2-х коров - WKP 1935/18/1; по вине каррекотурь допущена ошибка - WKP 1933/18/2; Гнать прямую роста темпов сева в-верх - WKP 1935/17/1; Дневные задание - ТВВ 1935/18/1; 1-ое мая встретим конианием сева - WКР 1933/18/1; выпелн в га - 1935/7/1; Засеяно рая сева - 1935/7/1; ответ [brak kropki] редактор - WKP 1935/18/1; вылолн [brak kropki] в га - ТВВ 1935/5/1 (4x); 1935/16/1; Засеяно ряд [brak kropki] сева - ТВB 1935/8/1 i in.

56 Także w specjalistycznych słownikach, np. w SIR (2001).

57 Por. лже - '[...] Первая часть составных слов, означающая [...] выдаваемый за кого-что-н.' (TSRJa). 
с погоней за количеством ударников илжеударниками - WКP 1933/16/1), кулаикозажиточный (ставит на работу кулацко-зажиточных лии - WKP 1933/16/2), киносрывщик (Киносрывщик [tytuł] - WKP 1933/16/2). W innym znaczeniu niż znaczenia notowane $\mathrm{w}$ słownikach użyto $\mathrm{w}$ prasie ASRR NP rzeczownika заделкa (Заделка сверх раннего сева - ТВВ 1935/5/1). Należało posłużyć się wyrazem задел (por. w SRJa: 'To, что выработано, сделано про запас').

Ze swoistych sowietyzmów warto odnotować rzeczownik кантон (соисоревнования по Кантону - WKP 1933/16/1), często - co naturalne - spotykany w prasie wychodzącej w ASRR NP, ale poza Republiką Niemców Powołża słabo znany. D. Uszakow uzupełnił artykuł hasłowy w TSRJa o nowe znaczenie tego wyrazu: 2. 'Официальное название административных подразделений нек-рых республик, входящих в состав СССР’, jednak redaktorzy późniejszych słowników z tego podpunktu zrezygnowali (por. SRJa).

$\mathrm{W}$ analizowanych gazetach rosyjskich znalazły też odbicie rozmaite skrótowce, będące - na równi z sowietyzmami - znakiem swojej epoki ${ }^{58}$. W badanym materiale przykuwają uwagę zwłaszcza skrótowce charakterystyczne dla ASRR NP, np. zbudowane na rzeczowniku кантон lub jego pochodnych (w słownikach, nawet specjalistycznych ${ }^{59}$, niepoświadczone), a mianowicie: КК ВЛКСM = Кантональный Комитет ВЛКСМ (Постановление Бюро Федоровского КК ВЛКСМ - WКР 1933/17/1; Орган Палласовского КК ВКП(б) - ТВВ 5/1935/1), КИК = кантональный исполнительный комитет (Орган КИК- $a$ - ТВВ 1935/18/1); КЗУ= кантональное земельное управление (по данным КЗУ - WКР 1933/16/2); Кантком = кантональный комитет (Отвечаем Канткому - WКР 1933/16/2; Орган Федоровского канткома ВКП(б) ТВВ 1935/18/1); Кантлит = кантональная литография (Кантлит, № 64 - ТВВ 5/1935/1; Кантлит № 65 - ТВВ 1935/7/1); Кантпрофсовет = кантональный профессиональный совет (Орган Кантпрофсовета - ТВВ 1935/18/1).

Zasługuje też na uwagę leksyka regionalna, trafiająca się na łamach gazet wydawanych po rosyjsku w ASRR NP. Mamy w tej grupie wyraz севеu, 'сеяльщик' (Лучшему севиу Кушумского $к$. - WKP 1933/16/1) ${ }^{60}$, тягло (за полное использование тягла и машин - WKP 1939/16/1) ${ }^{61}$, боронба ${ }^{62}$ (В боронбе при запряжке 2-х коров в два следа норма выработки 2,5 га, а нужно 1,5 га - WKP 1933/18/2). Poza tym

58 Por. „Наиболее заметным и в определенной степени существенным новшеством [...] оказалась аббревиатура [...]. Теперь аббревиатура стала непременным элементом почти каждой фразы” (А. Фесенко \& Т. Фесенко, 1955, s. 170). O radzieckich skrótowcach i ich innojęzycznych ekwiwalentach zob. m.in.: Mędelska, 2011; Sobczak, 2012; Собчак, 2011, 2012, 2013.

59 Zob. NSSRJa (1995).

${ }^{60}$ W TSRJa opatrzony kwalifikatorem обл. спец. ('Тот, что сеет, сеяльщик').

${ }^{61}$ TSRJa notuje jako обл. c.-x. (ma też połączenie тяглый скот).

${ }^{62} \mathrm{Z}$ błędem ortograficznym, powinno być: бороньба (w TSRJa z kwalifikatorem обл.). 
TSRJa nie notuje terminu rolniczego весновспашка ${ }^{63}$ występującego w badanej prasie (Сев, весновспашка - TBB 1935/5/1). Jednostka ta trafiła dopiero do SRJa-I, który ukazał się pod koniec lat 50. XX w.

Z kolei w radzieckich gazetach wydawanych po niemiecku w ASRR NP w latach 20. i 30. XX w. najbardziej interesujące są sowietyzmy ${ }^{64}$. W pośpiesznie przygotowywanej prasie o charakterze wybitnie propagandowym najczęściej spotyka się doraźne pożyczki formalno-semantyczne $\mathrm{z}$ rosyjskiego, naprędce adaptowane do systemu języka niemieckiego. Trzeba tu wskazać przede wszystkim rzeczownik Kolchos (Vorsitz. d. Kolchos: Wulf A., Vorsitz. d. Kolchos - Maier, Vorsitz. d. Kolchos: Fedulow WBB 1935/7/2), który z czasem wszedł do języka niemieckiego używanego w Niemczech (zob. WDW, 1986), jak i do wielu innych języków, czyli stał się internacjonalizmem. Zasięg regionalny, ograniczony do terytorium ZSRR, miały natomiast sowietyzmy Partorg 'organizator partyjny' ${ }^{65}$ (Partorg: Heinze, Partorg: Hasselbach, Partorg: Oparie - WBB 1935/7/2) i Smytschka 'więź; ogniwo' ${ }^{66}$ (Komm[ando]. „Smytschka”67 WBB 1935/5/2). Obie pożyczki były powszechne w języku Niemców rosyjskich, por. m.in. przykłady z wydawanego w Engelsie miesięcznika „Der Kämpfer” (DK): [...] gab der Partorg dem Gespräch eine sachliche Wendung [...] (DK 1935/7/20); Gespannte Gesichter. Was ist das, mit der umgekehrten Smitschka? (DK 1935/7/337). Zdaniem Nikołaja Biernikowa, takie wyrazy jak nasza Smytschka, a także Sowjet, Subbotnik i wiele innych są sowietyzmami w wąskim znaczeniu. To wyrazy radziecko-rosyjskie związane znaczeniowo z ogólnozwiązkową praktyką socjalistyczną, które funkcjonują w języku niemieckim w takiej postaci, w jakiej są używane w rosyjskim i w wielu innych językach ZSRR (Берников, 1941, s. 259).

Do radzieckich neologizmów semantycznych w języku Niemców nadwołżańskich trzeba też zaliczyć wyraz Kanton 'jednostka podziału administracyjnego ASRR NP' (Pallasowkaer Kanton - WBB 1935/1/2; 1935/5/2), w niemczyźnie używanej na terytorium etnicznym nieznany (WDW, 1986 wskazuje tylko Szwajcarię, Belgię i Prusy).

W badanej prasie niemieckiej trafiały się też sowietyzmy będące kalkami strukturalno-semantycznymi wzorców rosyjskich, np.: Rote Tafel 'tablica honorowa', ros. красная доска ${ }^{68}$ (Rote Tafel - TBB 1935/1/2; 1935/5/1; 1935/7/2; 1935/8/2) i Schwarze Tafel 'tablica hańby', ros. черная доска ${ }^{69}$ (Schwarze Tafel - TBB 1935/1/2; 1935/5/1;

\footnotetext{
63 'Весенняя вспашка не вспаханных под зябь полей' (SRJa-I).

64 Zob. też Mędelska \& Cieszkowski, 2012.

${ }^{65}$ WDW nie notuje.

66 WDW nie notuje.

67 Tu jako nazwa własna (ale banalna, występująca powszechnie, nadużywana).

${ }^{68} \mathrm{~W}$ rosyjskim porewolucyjny neologizm, por. w TSRJa: нов. 'доска, на которой вывешивается список отличившихся в чем-н.'.

69 W TSRJa: нов. 'доска, на которой вывешивается список провинившихся в чем-н.'.
} 
1935/7/2; 1935/8/2). Jak pod koniec lat 30. XX w. zauważył N. Bernikow, język niemiecki, tak jak i inne języki narodów zamieszkujących ZSRR, ,kalkuje” zmiany semantyczne w rosyjskim, języku komunikacji wewnątrzzwiązkowej. Jako najwyrazistsze kalki tego rodzaju badacz podaje te, które przekazują treść pojęć o znaczeniu ogólnozwiązkowym, a mianowicie: Rote Ecke, Rote Tafel, Dreieck i wiele innych (Берников, 1941, s. 259).

Tak, jak i radzieckie gazety rosyjskie, prasa niemiecka wydawana w ASRR NP upstrzona była rozmaitymi skrótowcami, obcymi niemczyźnie ogólnej ${ }^{70}$, np.: KK der AP(B)SU (WBB 1935/1/2; 1935/5/2; 1935/7/2; 1935/8/2), KVA der ASSR der WD (WBB 1935/1/2; 1935/5/2; 1935/7/2; 1935/8/2), KW (Benennung der KW - WBB 1935/5/2, 1935/7/2), MTS (Pallasowkaer MTS, Sawinkaer MTS - WBB 1935/1/2; 1935/5/2). N. Biernikow uważa je za szczególną odmianę sowietyzmów, zazwyczaj funkcjonującą w języku Niemców Powołża jako w całości zapożyczone wyrazy, np. Raykom, Kantkom, Komsorg, ZK, MTS, TschTS, Kono, ZIK i in. (Берников, 1941, s. 259).

Na zakończenie jeszcze garść osobliwości języka Niemców rosyjskich odzwierciedlonych w periodyku „Der Kämpfer”. Ten miesięcznik, ukazujący się w Engelsie w latach 1932-1939, redagował Gerhard Sawatzky (Busch, 1997, s. 517). Oto wybrane regionalne niemieckie jednostki słownikowe powstałe wskutek oddziaływania języka rosyjskiego $^{71}$ : Ambar, niem: Speicher, ros.: aмбap (Und Weber, sagte er, hat einen Ambar voll, den soll er geben und nicht für die Weißen aufheben und nicht zu Schnaps verkochen! - DK 1936/10/36); Arbuse, niem: Wassermelone, ros.: ap6y3 (Noch nie im Leben hatte er solchen unbändigen Hunger nach Arbusen - DK 1935/8-9/54, 55, 56, 57); Batrake, niem: Kossäte, ros.: бampaא (Im ersten und im zweiten Jahr wird er mit einem andern Batraken, der auch ein Pferd hat, zusammenspannen (DK 1935/3-4/23); Otlitschnik, niem: bester Schüler, ros.: отличник (Die ganze Abteilung beweint den mustergültigen Otlitschnik im Dienst und seelenguten Genossen Alexander Dobranov - DK 1938/5/39); Prädsidatel, niem: Vorsitzende, ros.: председатель (Unser Prädsidatel, unser Pius Spannenberg: Hurra! - DK 1938/6-7/37); Putjowka, niem: Einweisung, ros.: nутевка (Sobald du die Putjowka hast, fragt niemand mehr nach deiner Gesundheit - DK/35/8-9/104) ${ }^{72}$. Wyrazy te nie trafiły do miesięcznika „Der Kämpfer" przypadkowo, lecz były w okresie porewolucyjnym w powszechnym obiegu. Dwa pierwsze: Ambar i Arbuse to pożyczki bardzo stare, przejęte jeszcze w XVIII-XIX w. przez pierwszych niemieckich kolonistów (Дингес, 1929, ss. 201, 211) i używane

${ }^{70}$ Zob. KWL (wydany w roku 1934).

${ }^{71}$ Materiał ten wyekscerpowała Maria Jankowiak-Rutkowska.

${ }^{72}$ Por. też jednostki powstałe pod wpływem rosyjskim, ale niemające odpowiedników w niemczyźnie etnicznej: Dorfsowjet (Und im ersten Dorfsowjet lassen wir uns registrieren - DK 1935/7/56); Kischlak (Dreimal lief ich um den Kischlak-DK 1935/7/52); MTS-Traktor (Der MTS-Traktor bearbeitet die Felder - DK 1935/5-6/87); Pionierführer („Kinder, beginnen wir unseren Wettlauf” ruft der Pionierführer - DK 1935/1/28). 
do dziś (Москалюк, 2003, s. 169; Mędelska, Cieszkowski, \& Jankowiak-Rutkowska, 2014), a np. rusycyzm Prädsedatel znany jest $\mathrm{z}$ mowy chłopa mieszkającego na wsi ukraińsko-niemieckiej w okresie międzywojennym ${ }^{73}$ (Жирмунский, 1933, s. 100) i z mowy Niemców zamieszkujących region ałtajski na przełomie lat 70. i 80. XX w. (Зинковская, 1981, s. 103).

Radziecka prasa niemiecka odzwierciedlała postępującą degradację języka niemieckiego używanego w ZSRR, jednocześnie tę złą kondycję niemczyzny utrwalając $\mathrm{i}$ - w jakimś sensie - sankcjonując. Jak jednak zauważył Wiktor Żyrmunskij, obserwując na zebraniach politycznych, w sądach itp. mowę nadwołżańskich niemieckich chłopów - kołchoźników, już w początkach lat 30. XX w. takie rusycyzmy, jak yдapнuк, уравниловка, обезличка itd., w mowie przodujących kołchoźników - aktywistów były zastępowane przez ich niemieckie odpowiedniki literackie. Działo się tak - zdaniem badacza - pod wpływem prasy radziecko-niemieckiej ${ }^{74}$, która znacznie wzbogaciła zasób leksykalny niemieckiego języka literackiego. Z kolei zacofane warstwy chłopstwa nadal w większości posługiwały się pożyczkami rosyjskimi (Жирмунский, 1933, ss. 100-101).

\section{Wykaz skrótów źródeł}

DK - „Der Kämpfer”. Monatsschrift für Literatur und Kunst. Organ des Bundes der Sowjetschriftsteller der ASSRdWD.

ТВВ - „Темпо. Ежедн. большевистский бюллетень”. Орган Палассовского КК ВКП(б) и КИК-а АССР НП // „Тетро. Alltägl. Bolschewistisches Bulletin”. Organ des Pallasowkaer KK der AP (B) SU und KVA der ASSR der WD.

WKP - „Вперед к победе. Однодневный выпуск”. Орган Федоровского канткома ВКП(б), КИК-а и Кантпрофсовета.

\section{Wykaz skrótów słowników}

KWL - E. Pfohl (Red.), Kurzwort-Lexikon, Stuttgart 1934.

NSSRJa - Е. Г. Коваленко, Новый словарь сокращений русского языка, Москва 1995.

SIR - Б.З. Букчина, Л. П. Калакуцкая, Слитно или раздельно, Москва 2001.

SRJa - А. П. Евгеньева (ред.), Словарь русского яыка, т. 1-4, Москва 1981-1984.

SRJa-I - А. П. Евгеньева (ред.), Словарь русского яыка, т. 1-4, Москва 1957-1961.

${ }^{73}$ Obok: Selbud, Aktivist, Paj, Sojus, Prodnalog, Raskulatschanje i in.

${ }^{74}$ W. M. Żyrmunski nazywa ја̨ „,оветско-немецкой”. 
SSSRL - Р.П. Рогожникова (ред.), Сводный словарь современной русской лексики, т. 1-2, Москва 1991.

TSRJa - Д. Н. Ушаков (ред.), Толковый словарь русского языка, т. 1-4, Москва 1934-1940.

WDW - Wahrig G., Deutsches Wörterbuch. Mit einem Lexikon der deutschen Sprachlehre, München 1986.

\section{Bibliografia}

Beratz, G. (1923). Die deutschen Kolonisten an der unteren Wolga in ihrer Entstehung und ersten Entwicklung. Berlin.

Bonwetsch, G. (1919). Geschichte der deutschen Kolonien an der Wolga. Stuttgart: Verl. J. Engelhorns Nachf.

Brandes, D. (1997). Einwanderung und Entwicklung der Kolonien. W G. Stricker (Red.), Deutsche Geschichte im Osten Europa: Rußland (ss. 35-110). Berlin: Siedler.

Busch, M. (1997). Presse in der Zwischenkriegszeit: Meinungsfreiheit oder Marionettentheater? W G. Stricker (Red.), Deutsche Geschichte im Osten Europa: Rußland (ss. 515-519). Berlin: Siedler.

Eisfeld, A. (1987). Autonome Sozialistische Sowjetrepublik der Wolgadeutschen - Chance oder Gefahrenherd? W A. Kappeler \& G. Meissner, Die Deutschen im Russischen Reich und im Sowjetstaat (ss. 49-67). Köln: Markus-Verl.

Engel-Braunschmidt, A. (1987). „National nach der Form, dem Inhalt nach sozialistisch”: zur besonderen Situation der deutschen Literatur in der Sowjetunion. W A. Kappeler \& G. Meissner, Die Deutschen im Russischen Reich und im Sowjetstaat (ss. 115-135). Köln: Markus-Verl.

Iwanow, M. (1991). Pierwszy naród ukarany: Polacy w Związku Radzieckim 1921-1939. Warszawa; Wrocław: Państwowe Wydawnictwo Naukowe.

Lebioda, T. (2004). Niemcy rosyjscy $w$ polityce RFN na tle ich znaczenia $w$ Rosji i relacjach niemiecko-rosyjskich $w$ latach 1763-2003. Wrocław: Arboretum.

Mędelska, J. (2010). Skrótowce porewolucyjne w pierwszych radzieckich słownikach dwujęzycznych. Acta Baltico-Slavica, 34, 73-88.

Mędelska, J., \& Cieszkowski, M. (2012). Pierwsze sowietyzmy w niemczyźnie współczesnej: na podstawie porewolucyjnego słownika rosyjsko-niemieckiego. W A. Kątny (Red.), Sprachund Kulturkontakte in Europas Mitte: Studien zur Slawistik und Germanistik (ss. 91-111). Frankfurt am Main: Lang-Ed.

Mędelska, J., Cieszkowski, M., \& Jankowiak-Rutkowska, M. (2014). О слове Arbuse, одном из первых русизмов в языке российских немцев, Jazykovedny с̌asopis, 65(cz. 1), 5-21.

Pfohl, E. (Red.). (1934). Kurzwort-Lexikon [KWL]. Stuttgart: Muth.

Pinkus, B., \& Fleischhauer, I. (1987). Die Deutschen in der Sowjetunion: Geschichte einer nationalen Minderheit im 20. Jh. (K.-H. Ruffmann, Red.). Baden-Baden: Nomos. 
Sinner, P. (1923). Kurzgefaßte Geschichte der deutschen Wolgakolonien. W Beiträge zur Heimatkunde des deutschen Wolgagebiets: mit einer Karte und einer Tabelle (ss. 5-28). Pokrowsk (Kosakenstadt): Abt. f. Volksbildung d. Gebiets d. Wolgadeutschen.

Sobczak, M. (2011). Pierwsze radzieckie skrótowce porewolucyjne w dwujęzycznym opisie leksykograficznym: zamierzenia badawcze. W В. П. Казарин (Red.), Крымско-польский сборник научных работ (ss. 225-228). Симферополь: Универсум.

Sobczak, M. (2012). Wybrane problemy przekładu skrótowców na podstawie rosyjsko-niemieckiego słownika A. Nesslera. W J. Mędelska \& E. Titarenko (Red.), Dialog kultur: języki wschodniosłowiańskie w kontakcie z polszczyzna i innymi językami europejskimi (ss. 211-223). Bydgoszcz - Symferopol: Wydawnictwo Uniwersytetu Kazimierza Wielkiego.

Stricker, G. (1997). Fragen an die Geschichte der Deutschen in Rußland. W G. Stricker (Red.), Deutsche Geschichte im Osten Europa: Rußland (ss. 13-20). Berlin: Siedler.

Wahrig, G. (1986). Deutsches Wörterbuch: mit einem Lexikon der deutschen Sprachlehre [WDW]. München: Mosaik-Verl.

Айсфельд, А. (1995). Положение колонистов Поволжья в политике германского Рейха во время I мировой войны. W E. А. Шервуд (Red.), Российские немцы на Дону, Кавказе и Волге: материаль Русско-Германской научной конференции, 22-26 сентября 1994 2. Москва (ss. 183-195). Москва.

Айсфельд, А. (2005). Национальная политика в СССР по отношению к немцам. W C. И. Бобылева (Red.), Вопросы германской истории: сборник научных работ (ss. 209-239). Днепропетровск.

Берников, Н. Н. (1941). Процесс перестройки фонетической структуры крестьянской речи: из наблюдений над современными немецко-волжскими языковыми отношениями”. Ученые записки ЛГУ. Серия филологических наук, выпуск 5(58), 255-291.

Бобылева, С. И., \& Кадол, А. Н. (2005). Антинемецкие кампании в России и судьбы немецкого населения в начальный период Первой мировой войны. W C. И. Бобылева (Red.), Bопросы германской истории: сборник научных работ (ss. 14-30). Днепропетровск.

Букчина, Б. 3., \& Калакуцкая, Л. П. (2001). Слитно или раздельно [SIR]. Москва.

Булычев, М. В. (1995). Экономика немецких колоний Саратовского края в первой половине XIX века. W Е. А. Шервуд (Red.), Российские немиы на Дону, Кавказе и Волге: Материалы Русско-Германской научной конферениии, 22-26 сентября 1994 г. Москва (ss. 164-173). Москва.

Герман, А. (2006а). Палласовский кантон. W O. Кубицкая et al. (Red.), Немцы России: эницилопедия (Т. 3, ss. 18-19). Москва: Издательство „Общественная Академия наук российских немцев".

Герман, А. (2006b). Федорковский кантон. W O. Кубицкая et al. (Red.), Немцы России: энииклопедия (T. 3, ss. 633-634). Москва: Издательство „Общественная Академия наук российских немцев".

Герман, А., \& Герман, Е. (2006). Республика немцев Поволжья. W O. Кубицкая et al. (Red.), Немиы России: энииклопедия (Т. 3, ss. 271-292). Москва: Издательство „Общественная Академия наук российских немцев". 
Герман, А., Иларионова, Т. С., \& Плеве, И. Р. (2007). История немцев России: Учебное пособие. Москва: МСНК-Пресс.

Герман, А., \& Плеве, И. Р. (2002). Немцы Поволжья: краткий исторический очерк. Саратов: Изд-во Сарат. ун-та.

Дизендорф, В.Ф. (Red.). (2006). Немцы России: населенные пункты и места населения. Энииклопедический словарь (приложение к: Немиь России: энииклопедия). Москва: Издательство „Общественная Академия наук российских немцев”.

Дингес, Г. Г. (1929). О русских словах, заимствованных поволжскими немцами до 1876 года. Ученые записки Саратовского государственного университета им. Н. Г. Чернышевского, 7, 195-236.

Дитц, Я. Е. (1997). История поволжских немцев-колонистов. (И. Р. Плеве, Red.). Москва.

Евгеньева, А. П. (Red.). (1981-1984). Словарь русского яыка [SRJa] (T. 1-4). Москва: Издательство „Русский язык”.

Евгеньева, А. П. (Red.). (1957-1961). Словарь русского яыка [SRJa-I] (T. 1-4). Москва.

Ерина, Е. М. (1995). Очерки истории культуры Немецкой автономии на Волге. Саратов.: Издат. Саратовского Унив.

Жирмунский, В. М. (1933). Итоги и задачи диалектологического и этнографического изучения немецких поселений СССР. Советская этнография, (2), 84-112.

Зинковская, Н. Я. (1981). Некоторые особенности языковой ситуации в населенных пунктах с русско-немецким населением. W Языки и топонимия Алтая: межвузовский сборник (ss. 98-106). Барнаул: Алтайский государственный университет.

Зиннер, П. И. (1925). Немцы Нижнего Поволжья: выдающиеся деятели из колоний Поволжья. Саратов.

Иларионова, Т. С. (2006). Печать российских немцев. W O. Кубицкая et al. (Red.), Немцы России: энииклопедия (T. 3, ss. 67-76). Москва: Издательство „Общественная Академия наук российских немцев".

Коваленко, Е. Г. (1995). Новый словарь сокращений русского языка [NSSRJa]. Москва: Издательство ЭТС.

Литвинова, И. Н. (2007). Немцы-предприниматели Саратовского края. W Н. Э. Вашкау (Red.), Русские и немиь: от противостояния к взаимодействию: материаль научнопрактического семинара „Проблемы историографии и источниковедения истории российских немиев", Волгоград (ss. 58-72). Волгоград.

Меромский, А. (1930). Язык селькора. Москва: Изд-во „Федерация”.

Москалюк, Л. И. (2003). Явления интерференции в лексико-семантической системе островных немецких говоров. W P. А. Томилов \& Т. Б. Смирнова (Red.), Немцы Сибири: история и культура (ss. 167-172). Новосибирск.

Остроух, И. Г., \& Шервуд, Е. А. (1995). Российские немцы: вклад в историю и культуру (XVII - начало XX вв.). W Е. А. Шервуд (Red.), Российские немиы на Дону, Кавказе и Волге: Материалы Русско-Германской научной конференции, 22-26 сентября 1994 г. Москва (ss. 11-25). Москва. 
Плеве, И. Р. (1995). Манифест Екатерины II от 22 июля 1763 г.: обещания и реальность. W E. А. Шервуд (Red.), Российские немиы на Дону, Кавказе и Волге: Материалы РусскоГерманской научной конферениии, 22-26 сентября 1994 г. Москва (ss. 26-32). Москва.

Плеве, И. Р. (2000). Немецкие колонии на Волге во второй половине XVIII века. Москва: Готика.

Приб, А. (2007). Немеццие колонисты России 1783-2006: исторический очерк. Augsburg: Waldemar Weber Verlag.

Рогожникова, Р. П. (Red.). (1991). Сводный словарь современной русской лексики [SSSRL] (Т. 1-2). Москва: Издательство „Русский язык”.

Смирницкая, С. В. (2002). Немецкоязычная пресса в России. W С. В. Смирницкая, Труды по германистике и истории языкознания (ss. 239-244). Санкт-Петербург: Наука.

Собчак, М. (2011). Структурные типы русских послереволюционных аббревиатур: на материале московского русско-польского словаря от 1933 года. Slavia Orientalis, 60(3), 405-417.

Собчак, М. (2012). Аббревиатурные образования - новое в русском языке XX века. W A. А. Билюкина (Red.), Новое в современной филологии: материаль VI Международной научно-практической конферениии (ss. 41-44). Москва.

Собчак, М. (2013). Аббревиатуры в русско-польской лексикографии XX века. W Т. А. Ященко (Red.), Материалы Международной научно-практической конференции, посвященной 45-летию кафедры методики преподавания филологических дисииплин и 40-летию международного образования в СНГ-ТНУ, Симферополь (ss. 72-74). Симферополь.

Ушаков, Д. Н. (Red.). (1934-1940). Толковый словарь русского языка [TSRJa] (T. 1-4). Москва. Фесенко, А., \& Фесенко, Т. (1955). Русский язык при советах. Нью-Йорк.

Фукс, В. Г. (1995). Роковые дороги поволжских немцев 1763-1995: исторические факты, документы, обращения к властям, письма, воспоминания лии преследуемого народа. Красноярск.

Чеботарева, В. Г. (1999). Государственная национальная политика в Республике немиев Поволжья: 1918-1941 г2. Москва.

\section{Bibliography (transliteration)}

Aŭsfel'd, A. (1995). Polozhenie kolonistov Povolzh'ia v politike germanskogo Reŭkha vo vremia I mirovor̆ vol̆ny. In E. A. Shervud (Ed.), Rossiǔskie nemtsy na Donu, Kavkaze $i$ Volge: materialy Russko-Germanskoŭ nauchnoı̆ konferentsii, 22-26 sentiabria 1994 g. Moskva (pp. 183-195). Moskva.

Aĭsfel'd, A. (2005). Natsional'naia polityka v SSSR po otnosheniiu k nemtsam. In S. I. Bobyleva (Ed.), Voprosy germanskoĭ istorii: sbornik nauchnykh rabot (pp. 209-239). Dnepropetrovsk.

Beratz, G. (1923). Die deutschen Kolonisten an der unteren Wolga in ihrer Entstehung und ersten Entwicklung. Berlin. 
Bernikov, N. N. (1941). Protsess perestroŭki foneticheskoŭ struktury krest'ianskoŭ rechi: iz nabliudeniı̆ nad sovremennymi nemetsko-volzhskimi iazykovymi otnosheniiami, Uchenye zapiski LGU. Seriia filologicheskikh nauk, vyp. 5(58), 255-291.

Bobyleva, S. I., \& Kadol, A. N. (2005). Antinemetskie kampanii v Rossii i sud'by nemetskogo naseleniia v nachal'nyı̆ period Pervor mirovor̆ voĭny. In S. I. Bobyleva (Ed.), Voprosy germanskoŭ istorii: sbornik nauchnykh rabot (pp. 14-30). Dnepropetrovsk.

Bonwetsch, G. (1919). Geschichte der deutschen Kolonien an der Wolga. Stuttgart: Verl. J. Engelhorns Nachf.

Brandes, D. (1997). Einwanderung und Entwicklung der Kolonien. In G. Stricker (Ed.), Deutsche Geschichte im Osten Europa: Rußland (pp. 35-110). Berlin: Siedler.

Bukchina, B. Z., \& Kalakutskaia, L. P. (2001). Slitno ili razdel'no [SIR]. Moskva.

Bulychev, M. V. (1995). Ėkonomika nemetskikh koloniǐ Saratovskogo kraia v pervoŭ polovine XIX veka. In E. A. Shervud (Ed.), Rossiüskie nemtsy na Donu, Kavkaze i Volge: materialy Russko-Germanskoĭ nauchnoĭ konferentsii, 22-26 sentiabria 1994 g. Moskva (pp. 164-173). Moskva.

Busch, M. (1997). Presse in der Zwischenkriegszeit: Meinungsfreiheit oder Marionettentheater? In G. Stricker (Ed.), Deutsche Geschichte im Osten Europa: Rußland (pp. 515-519). Berlin: Siedler.

Chebotareva, V. G. (1999). Gosudarstvennaia natsional'naia politika v Respublike nemtsev Povolzh'ia: 1918-1941 gg. Moskva.

Dinges, G. G. (1929). O russkikh slovakh, zaimstvovannykh povolzhskimi nemtsami do 1876 goda. Uchenye zapiski Saratovskogo gosudarstvennogo universiteta im. N. G. Chernyshevskogo, 7, 195-236.

Ditts, IA. E. (1997). Istoriia povolzhskikh nemtsev-kolonistov. (I. R. Pleve, Ed.). Moskva.

Dizendorf, V. F. (Ed.). (2006). Nemtsy Rossii: naselennye punkty i mesta naseleniia. Entsiklopedicheskiŭ slovar' (prilozhenie : Nemtsy Rossii: éntsiklopediia). Moskva: Izdatel'stvo «Obshchestvennaia Akademiia nauk rossiǐskikh nemtsev».

Eisfeld, A. (1987). Autonome Sozialistische Sowjetrepublik der Wolgadeutschen - Chance oder Gefahrenherd? In A. Kappeler \& G. Meissner, Die Deutschen im Russischen Reich und im Sowjetstaat (pp. 49-67). Köln: Markus-Verl.

Engel-Braunschmidt, A. (1987). „National nach der Form, dem Inhalt nach sozialistisch”: zur besonderen Situation der deutschen Literatur in der Sowjetunion. In A. Kappeler \& G. Meissner, Die Deutschen im Russischen Reich und im Sowjetstaat (pp. 115-135). Köln: Markus-Verl.

Erina, E. M. (1995). Ocherki istorii kul'tury Nemetskoĭ avtonomii na Volge. Saratov: Izdat. Saratovskogo Univ.

Evgen'eva, A. P. (Ed.). (1957-1961). Slovar' russkogo iazyka [SRJa-I] (Vols. 1-4). Moskva.

Evgen'eva, A. P. (Ed.). (1981-1984). Slovar' russkogo iazyka [SRJa] (Vols. 1-4). Moskva: Izdatel'stvo «Russkiǐ iazyk».

Fesenko, A., \& Fesenko, T. (1955). Russkiŭ iazyk pri sovetakh. N'iu-Ǐork. 
Fuks, V. G. (1995). Rokovye dorogi povolzhskikh nemtsev 1763-1995: istoricheskie fakty, dokumenty, obrashcheniia $k$ vlastiam, pis'ma, vospominaniia lits presleduemogo naroda. Krasnoiarsk.

German, A. (2006a). Pallasovskiı̌ kanton. In O. Kubitskaia et al. (Ed.), Nemtsy Rossii: èntsiklopediia (Vol. 3, pp. 18-19). Moskva: Izdatel’stvo «Obshchestvennaia Akademiia nauk rossiǔskikh nemtsev».

German, A. (2006b). Fedorkovskiĭ kanton. In O. Kubitskaia et al. (Ed.), Nemtsy Rossii: entsiklopediia (Vol. 3, pp. 633-634). Moskva: Izdatel'stvo «Obshchestvennaia Akademiia nauk rossiǔskikh nemtsev».

German, A., \& German, E. (2006). Respublika nemtsev Povolzh'ia. In O. Kubitskaia et al. (Ed.), Nemtsy Rossii: entsiklopediia (Vol. 3, pp. 271-292). Moskva: Izdatel'stvo «Obshchestvennaia Akademiia nauk rossiǔskikh nemtsev».

German, A., \& Pleve, I. R. (2002). Nemtsy Povolzh'ia: kratkiu istoricheskiŭ ocherk. Saratov: Izd-vo Sarat. un-ta.

German, A., Ilarionova, T. S., \& Pleve, I. R. (2007). Istoriia nemtsev Rossii: uchebnoe posobie. Moskva: MSNK-Press.

Ilarionova, T. S. (2006). Pechat' rossiǔskikh nemtsev. In O. Kubitskaia et al. (Ed.), Nemtsy Rossii: entsiklopediia (Vol. 3, pp.67-76). Moskva: Izdatel'stvo «Obshchestvennaia Akademiia nauk rossiǔskikh nemtsev».

Iwanow, M. (1991). Pierwszy naród ukarany: Polacy w Związku Radzieckim 1921-1939. Warszawa; Wrocław: Państwowe Wydawnictwo Naukowe.

Kovalenko, E. G. (1995). Novyĭ slovar' sokrashcheniǔ russkogo iazyka [NSSRJa]. Moskva: Izdatel'stvo ĖTS.

Lebioda, T. (2004). Niemcy rosyjscy $w$ polityce RFN na tle ich znaczenia $w$ Rosji i relacjach niemiecko-rosyjskich w latach 1763-2003. Wrocław: Arboretum.

Litvinova, I. N. (2007). Nemtsy-predprinimateli Saratovskogo kraia. In N. Ė. Bashkau (Ed.), Russkie i nemtsy: ot protivostoianiia $k$ vzaimodeǐstviiu: materialy nauchno-prakticheskogo seminara "Problemy istoriografii i istochnikovedeniia istorii rossiüskikh nemtsev», Volgograd (pp. 58-72). Volgograd.

Mędelska, J. (2010). Skrótowce porewolucyjne w pierwszych radzieckich słownikach dwujęzycznych. Acta Baltico-Slavica, 34, 73-88.

Mędelska, J., \& Cieszkowski, M. (2012). Pierwsze sowietyzmy w niemczyźnie współczesnej: na podstawie porewolucyjnego słownika rosyjsko-niemieckiego. In A. Kątny (Ed.), Sprachund Kulturkontakte in Europas Mitte: Studien zur Slawistik und Germanistik (pp. 91-111). Frankfurt am Main: Lang-Ed.

Mędelska, J., Cieszkowski, M., \& Jankowiak-Rutkowska, M. (2014). O slove Arbuse, odnom iz pervykh rusizmov v iazyke rossiřskikh nemtsev, Jazykovedny časopis, 65 (cz. 1), 5-21.

Meromskiĭ, A. (1930). IAzyk sel'kora. Moskva: Izd-vo "Federatsiia”.

Moskaliuk, L. I. (2003). IAvleniia interferentsii v leksiko-semanticheskor sisteme ostrovnykh nemetskikh govorov. In R. A. Tomilov \& T. B. Smirnova (Eds.), Nemtsy Sibiri: istoriia i kul'tura (pp. 167-172). Novosibirsk. 
Ostroukh, I. G., \& Shervud, E. A. (1995). Rossiǐskie nemtsy: vklad v istoriiu i kul'turu (XVII nachalo XX vv.). In E. A. Shervud (Ed.), Rossiǔskie nemtsy na Donu, Kavkaze $i$ Volge: materialy Russko-Germanskoĭ nauchnoı̆ konferentsii, 22-26 sentiabria 1994 g. Moskva (pp. 11-25). Moskva.

Pfohl, E. (Ed.). (1934). Kurzwort-Lexikon [KWL]. Stuttgart: Muth.

Pinkus, B., \& Fleischhauer, I. (1987). Die Deutschen in der Sowjetunion: Geschichte einer nationalen Minderheit im 20. Jh. (K.-H. Ruffmann, Ed.). Baden-Baden: Nomos.

Pleve, I. R. (1995). Manifest Ekateriny II ot 22 iiulia 1763 g.: obeshchaniia i real'nost'. In E. A. Shervud (Ed.), Rossiǔskie nemtsy na Donu, Kavkaze i Volge: materialy Russko-Germanskoŭ nauchnoĭ konferentsii, 22-26 sentiabria 1994 g. Moskva (pp. 26-32). Moskva.

Pleve, I. R. (2000). Nemetskie kolonii na Volge vo vtorő̆ polovine XVIII veka. Moskva: Gotika.

Prib, A. (2007). Nemetskie kolonisty Rossii 1783-2006: istoricheskiŭ occherk. Augsburg: Waldemar Weber Verlag.

Rogozhnikova, R. P. (Ed.). (1991). Svodnyi slovar' sovremennoĭ russkoĭ leksiki [SSSRL] (Vols. 1-2). Moskva: Izdatel'stvo «Russkiı̌ iazyk».

Sinner, P. (1923). Kurzgefaßte Geschichte der deutschen Wolgakolonien. In Beiträge zur Heimatkunde des deutschen Wolgagebiets: mit einer Karte und einer Tabelle (pp. 5-28). Pokrowsk (Kosakenstadt): Abt. f. Volksbildung d. Gebiets d. Wolgadeutschen.

Smirnitskaia, S. V. (2002). Nemetskoiazychnaia pressa v Rossii. In S. V. Smirnitskaia, Trudy po germanistike $i$ istorii iazykoznaniia (pp. 239-244). Sankt-Peterburg: Nauka.

Sobchak, M. (2011). Strukturnye tipy russkikh poslerevoliutsionnykh abbreviatur: na materiale moskovskogo russko-pol'skogo slovaria ot 1933 goda. Slavia Orientalis, 60 (3), 405-417.

Sobchak, M. (2012). Abbreviaturnye obrazovaniia - novoe v russkom iazyke XX veka. In A. A. Biliukina (Ed.), Novoe v sovremennő̆ filologii: materialy VI Mezhdunarodnő nauchno-prakticheskoĭ konferentsii (pp. 41-44). Moskva.

Sobchak, M. (2013). Abbreviatury v russko-pol'skoĭ leksikografii XX veka. In T. A. IAshchenko (Ed.), Materialy Mezhdunarodnoı̆ nauchno-prakticheskoŭ konferentsii, posviashchenno 45-letiiu kafedry metodyki prepodavaniia filologicheskikh distsiplin i 40-letiiu mezhdunarodnogo obrazovaniia v SNG-TNU, Simferopol' (pp. 72-74). Simferopol'.

Sobczak, M. (2011). Pierwsze radzieckie skrótowce porewolucyjne w dwujęzycznym opisie leksykograficznym: zamierzenia badawcze. In V. P. Kazarin (Ed.), Krymsko-pol'skiu sbornik nauchnykh rabot (pp. 225-228). Simferopol': Universum.

Sobczak, M. (2012). Wybrane problemy przekładu skrótowców na podstawie rosyjsko-niemieckiego słownika A. Nesslera. In J. Mędelska \& E. Titarenko (Eds.), Dialog kultur: języki wschodniosłowiańskie w kontakcie z polszczyzna i innymi językami europejskimi (pp. 211-223). Bydgoszcz - Symferopol: Wydawnictwo Uniwersytetu Kazimierza Wielkiego.

Stricker, G. (1997). Fragen an die Geschichte der Deutschen in Rußland. In G. Stricker (Ed.), Deutsche Geschichte im Osten Europa: Rußland (pp. 13-20). Berlin: Siedler.

Ushakov, D. N. (Ed.). (1934-1940). Tolkovyı̆ slovar' russkogo iazyka [TSRJa] (Vols. 1-4). Moskva. Wahrig, G. (1986). Deutsches Wörterbuch: mit einem Lexikon der deutschen Sprachlehre [WDW]. München: Mosaik-Verl. 
Zhirmunskiǔ, V. M. (1933). Itogi i zadachi dialektologicheskogo i ètnograficheskogo izucheniia nemetskikh poseleniǔ SSSR. Sovetskaia ètnografiia, (2), 84-112.

Zinkovskaia, N. IA. (1981). Nekotorye osobennosti iazykovor situatsii v naselennykh punktakh s russko-nemetskim naseleniem. In IAzyki i toponimiia Altaia: mezhvuzovskiu sbornik (pp. 98-106). Barnaul: Altă̌skiŭ gosudarstvennyı̆ universitet.

Zinner, P. I. (1925). Nemtsy Nizhnego Povolzh'ia: vydaiushchiesia deiateli iz koloniŭ Povolzh'ia. Saratov.

\section{Streszczenie}

Autorka przedstawiła pokrótce najważniejsze fakty $z$ historii Niemców rosyjskich (od Manifestu Katarzyny II po powołanie Autonomicznej Socjalistycznej Republiki Radzieckiej Niemców Powołża), zarysowując na tym tle dzieje prasy niemieckojęzycznej w Rosji i wczesnym ZSRR. Skupiła się głównie na tzw. nowej leninowskiej polityce narodowościowej i jej konsekwencjach dla mniejszości niemieckiej.

W latach 20. i 30. XX w. w ASRR NP zaczęto masowo drukować po niemiecku książki, podręczniki, broszury, dokumenty, sprawozdania, zwłaszcza zaś materiały propagandowe i prasę. Nowa polityka narodowościowa władz radzieckich sprowadzała się oczywiście do szybkiego i sprawnego indoktrynowania mniejszości narodowych, „wychowywania” ich w duchu ideologii komunistycznej. Dla partii bolszewickiej gazety były zbiorowym propagandystą i agitatorem. Do połowy lat 20 . XX w. drukowano w całym ZSRR ponad 70 periodyków niemieckojęzycznych. W Republice Niemców Powołża wydawano 21 gazet w języku niemieckim, m.in. specjalistyczne „Wolgadeutsches Schulblatt”, „Sei bereit”, „Rote Jugend”, głównie jednak prasę kantonową, kołchozową, sowchozową, a nawet gazety ośrodków maszynowych („Lenins Weg”, „Tempo. Bolschewistisches Alltägl. Bulletin”). Często wydawano gazety w języku rosyjskim i ich wersje niemieckojęzyczne, np. „Трудовая правда” і „Arbeiterwahrheit”. Wychodziła też prasa w języku rosyjskim, m.in. „Вперед к победе”. Kwalifikacje dziennikarzy były niskie. Gazety nagminnie zamieszczały relacje tzw. „rabkorów” (korespondentów robotniczych) i „sielkorów” (korespondentów wiejskich), ludzi do niedawna bardzo dalekich od przelewania myśli na papier. Na łamach prasy odzwierciedliła się degradacja języka niemieckiego w ZSRR, jego zaśmiecenie rusycyzmami, zwłaszcza sowietyzmami, w tym osobliwymi skrótowcami (np. Ambar, Arbuse, Batrake, Otlitschnik, Partorg, Smytschka, Rote Tafel, Schwarze Tafel, KK der AP(B)SU, KVA der ASSR der WD, MTS).

Słowa kluczowe: prasa niemiecka w ZSRR; dzieje; szata językowa 


\section{The soviet press in the Volga German Autonomous Soviet Socialist Republic in the 1930s. Introduction to the topic and remarks regarding language}

\section{Summary}

The author presents in brief the most significant facts from the history of Germans in Russia (from the Manifesto of Catherine II through the formation of the Volga German Autonomous Soviet Socialist Republic), outlining on this background the activities of the German language press in the Russia and in the early Soviet Union, with a primary focus on the so-called new ethnicities policy and its consequences for the German minority.

In the 1920s and 1930s in the VG ASSR, publication of books, textbooks, brochures, documents and reports in German began on a massive scale, especially press and propaganda materials. The new ethnicities policy of the Soviet authorities naturally boiled down to the rapid and proper indoctrination of ethnic minorities, "educating" them in the spirit of communist ideology. For the Bolshevik party newspapers were instruments of comprehensive propaganda and agitation.

Until the mid-1920s, over 70 periodicals were published in German in the entire USSR. In the Volga German Republic, 21 newspapers were published in German, including the specialized Wolgadeutsches Schulblatt, Sei Bereit, Rote Jugend, but mainly press for the canton, the kolkhoz or sovkhoz level, and even papers for machinists (Tempo. Bolschewistisches Alltägl. Bulletin, Lenins Weg). Frequently the periodicals were published in Russian alongside a German-language version, e.g. Трудовая правда and Arbeiterwahrheit, as well as publications in Russian only, including Виеред к победе.

The journalists' qualifications were very low. Periodicals frequently contained reports by "rabkors" (worker correspondents) and "selkors" (village correspondents), people for whom only very recently had been quite far removed from pouring out their thoughts on paper. The pages of the papers reflected the degradation of the German language used in the USSR, its mixing with Russianisms, especially Sovietisms, including peculiar acronyms (e.g. Ambar, Arbuse, Batrake, Otlitschnik, Partorg, Smytschka, Rote Tafel, Schwarze Tafel, KK der AP(B)SU, KVA der ASSR der WD, MTS).

Keywords: German press in the USSR; activities; linguistic style 